$5-2006$

\title{
Stresses in Proton Exchange Membranes Due to Hygro-Thermal Loading
}

Yaliang Tang

University of Delaware

Michael H. Santare

University of Delaware

Anette M. Karlsson

Cleveland State University, a.karlsson@csuohio.edu

Simon Cleghorn

Gore Fuel Cell Technologies

William B. Johnson

Gore Fuel Cell Technologies

Follow this and additional works at: https://engagedscholarship.csuohio.edu/enme_facpub

Part of the Mechanical Engineering Commons

How does access to this work benefit you? Let us know!

\section{Original Citation}

Tang, Y., Santare, M. H., Karlsson, A. M., 2006, "Stresses in Proton Exchange Membranes due to HygroThermal Loading," Journal of Fuel Cell Science and Technology, 3(2) pp. 119-124.

This Article is brought to you for free and open access by the Mechanical Engineering Department at EngagedScholarship@CSU. It has been accepted for inclusion in Mechanical Engineering Faculty Publications by an authorized administrator of EngagedScholarship@CSU. For more information, please contact library.es@csuohio.edu. 


\section{Stresses in Proton Exchange Membranes Due to Hygro-Thermal Loading}

Anette M. Karlsson

Department of Mechanical Engineering, University of Delaware, Newark, DE 19716

\section{Simon Cleghorn \\ William B. Johnson \\ Gore Fuel Cell Technologies, Elkton, MD 21922}

\begin{abstract}
Durability of the proton exchange membrane (PEM) is a major technical barrier to the commercial viability of polymer electrolyte membrane fuel cells (PEMFC) for stationary and transportation applications. In order to reach Department of Energy objectives for automotive PEMFCs, an operating design lifetime of at least $5000 \mathrm{~h}$ over a broad temperature range is required. Reaching these lifetimes is an extremely difficult technical challenge. Though good progress has been made in recent years, there are still issues that need to be addressed to assure successful, economically viable, long-term operation of PEM fuel cells. Fuel cell lifetime is currently limited by gradual degradation of both the chemical and hygro-thermomechanical properties of the membranes. Eventually the system fails due to a critical reduction of the voltage or mechanical damage. However, the hygro-thermomechanical loading of the membranes and how this effects the lifetime of the fuel cell is not understood. The long-term objective of the research is to establish a fundamental understanding of the mechanical processes in degradation and how they influence the lifetime of PEMFCs based on perfluorosulfuric acid membrane. In this paper, we discuss the finite element models developed to investigate the in situ stresses in polymer membranes.
\end{abstract}

\section{Introduction}

Polymer electrolyte membrane fuel cells (PEMFCs) are expected to become a prominent technology in a variety of energy generation applications, including stationary, portable, and automotive power sources. PEMFCs offer the potential advantages of high energy density, high efficiency, and clean operations, as well as providing the opportunity for greater energy security $[1,2]$. However, there are still a number of technical barriers that must be overcome before PEMFCs can realize their commercial potential. Probably the most challenging application for the PEMFC is in the transportation arena, where the fuel cell must displace the incumbent internal combustion engine technology. The higher temperature, and dryer operating conditions compared with stationary applications, combined with the need for robust performance in automotive duty cycle power transience imposes especially demanding requirements on the membrane electrode assembly (MEA) technology. The Department of Energy has outlined the durability targets for automotive fuel cells, which include $5000 \mathrm{~h}$ operational life over a full range of operation temperatures $\left(-40^{\circ} \mathrm{C}\right.$ to $\left.120^{\circ} \mathrm{C}\right)$ [3].

A typical unit cell of a PEMFC is made of a membrane electrode assembly (MEA) sandwiched between two gas diffusion layers (GDL). These are in turn compressed on either side by bipolar plates, which are generally graphite or metallic plates with gas flow channels formed in them. The MEA is the core component of PEMFC and consists of an ion conducting polymer electrolyte membrane with electrodes attached to each side. In a typical fuel cell stack many unit cells will be stacked together in series and clamped between end-plates to obtain the desired voltage and power requirements.

There has been very little work published on the effects of automotive duty cycles upon the operational life of the components comprising the PEMFC unit cell. An automotive duty cycle is likely to not only impose rapid changes in the current density and voltage of the cell, but also result in changes in the cell temperature, pressure, reactant flow rates and relative humidity.
As a result of in the changes in temperature and moisture, the PEM, GDL and bipolar plates will all experience expansion and contraction. Because of the different thermal expansion and swelling coefficients between these materials, hygrothermal stresses are expected to be introduced into the unit cell during operation. In addition, the nonuniform current and reactant flow distributions in the cell may result in nonuniform temperature and moisture content of the cell [4] which could in turn, potentially causing localized increases in the stress magnitudes.

In use, the PEM must provide proton transport from anode to cathode, while acting as an electronic insulator and a gas barrier to prevent mixing of oxygen and hydrogen. Any discontinuity of the membrane will result in failure of the fuel cell. Several publications have reported the importance of the membranes mechanical properties on operational life. Mechanical failures in the MEA have been reported after thermal and hydration cycling during fuel cell service [5-7,22]. These failures can appear as pinholes in the membrane or delamination between the MEA and GDL $[5,6]$. Studies [7] show that hygrothermal stresses might be an important reason for such failure. Weber and Newman [7] pointed out that mechanical stresses may be particularly important in systems that are nonisothermal.

The need for improved lifetime of PEMFCs necessitates that the failure mechanisms be clearly understood and life prediction models be developed, so that new designs can be introduced to improve long-term performance. To the author's knowledge, Webber and Newman's paper [7] is the first to incorporate the effect of mechanical stresses into a fuel cell model. However, their model is one-dimensional and does not include the effects of material property mismatch among PEM, GDL, and bipolar plates. The goal of the current investigation is to study the hygro and thermal stresses in different fuel cell assembly structures as they interact under environments approaching realistic conditions.

\section{Model Definition}

In order to keep a tractable set of parameters, several simplifying assumptions have been made in the development of this preliminary finite element model (Table 1). Whereas the actual system is three-dimensional, our model to-date is two dimensional. 
Table 1 Model assumptions

\begin{tabular}{|c|c|c|}
\hline Initial model parameters & Actual fuel cell & Future work \\
\hline 2D & 3D & $3 \mathrm{D}$ \\
\hline No internal heat generation & $\begin{array}{l}\text { Resistive, reaction and } \\
\text { strain induced heat } \\
\text { generated in cell }\end{array}$ & $\begin{array}{l}\text { Provide internal heat-source } \\
\text { term }\end{array}$ \\
\hline $\begin{array}{l}\text { Simplified temperature and } \\
\text { humidity profile }\end{array}$ & $\begin{array}{l}\text { Varying } T \text { and humidity } \\
\text { across active area }\end{array}$ & $\begin{array}{l}\text { Vary } T \text { and humidity and } \\
\text { heat generation across an } \\
\text { active area }\end{array}$ \\
\hline $\begin{array}{l}\text { Electrode layer not } \\
\text { considered separately from } \\
\text { GDL }\end{array}$ & $\begin{array}{l}\text { Electrode layer separate and } \\
\text { distinct from gas diffusion } \\
\text { layer }\end{array}$ & $\begin{array}{l}\text { Include separate electrode } \\
\text { layer }\end{array}$ \\
\hline $\begin{array}{l}\text { Step-changes of } T \text { and } \\
\text { humidity }\end{array}$ & $\begin{array}{l}T \text { and humidity changes } \\
\text { controlled by operating } \\
\text { conditions so vary } \\
\text { continually and } \\
\text { nonuniformly } \\
\text { across an active area } \\
\text { in all three dimensions }\end{array}$ & $\begin{array}{l}\text { Couple } T \text { and humidity } \\
\text { changes based on heat } \\
\text { generation term }\end{array}$ \\
\hline $\begin{array}{l}\text { Temperature and humidity } \\
\text { are independent and } \\
\text { uncoupled }\end{array}$ & $T$ and humidity are coupled & $\begin{array}{l}\text { Couple } T \text { and humidity as } \\
\text { determined from } \\
\text { experimental data }\end{array}$ \\
\hline $\begin{array}{l}\text { Isotropic material } \\
\text { parameters }\end{array}$ & $\begin{array}{l}\text { Nonisotropic material } \\
\text { behavior }\end{array}$ & $\begin{array}{l}\text { Use experimentally } \\
\text { measured nonisotropic } \\
\text { behavior of key internal } \\
\text { materials }\end{array}$ \\
\hline $\begin{array}{l}\text { Linear-elastic behavior of } \\
\text { all components }\end{array}$ & $\begin{array}{l}\text { Viscoelastic-viscoplastic } \\
\text { response }\end{array}$ & $\begin{array}{l}\text { Use elastic-plastic response } \\
\text { as function of } T \text { and } \\
\text { humidity for key internal } \\
\text { materials }\end{array}$ \\
\hline
\end{tabular}

An operating fuel cell has varying local conditions of temperature, humidity, and power generation (and thereby heat generation) across the active area of the fuel cell [8-17]. In this preliminary model, a simplified temperature and humidity profile was assumed in order to demonstrate the effects these variables can have on the stress state of the system. An illustrative temperature profile has been estimated as follows: cathode/GDE (gas diffusion electrode) and anode/GDE interface temperatures of $86^{\circ} \mathrm{C}$ and $85^{\circ} \mathrm{C}$, respectively, are fixed. These values are reasonable for a fuel cell operating at $80^{\circ} \mathrm{C}$ under typical conditions [18]. The bipolar plate is assumed to have a constant temperature at its midplane, and is set to the cell operating temperature of $80^{\circ} \mathrm{C}$. The model then calculates the internal temperature distribution profile produced from these boundary conditions. The resulting temperature profile is shown in Fig. 1.

As a first approximation, and to reduce the computational complexity in the model, the humidity profile has been assumed uniform throughout the membrane. The initial relative humidity of

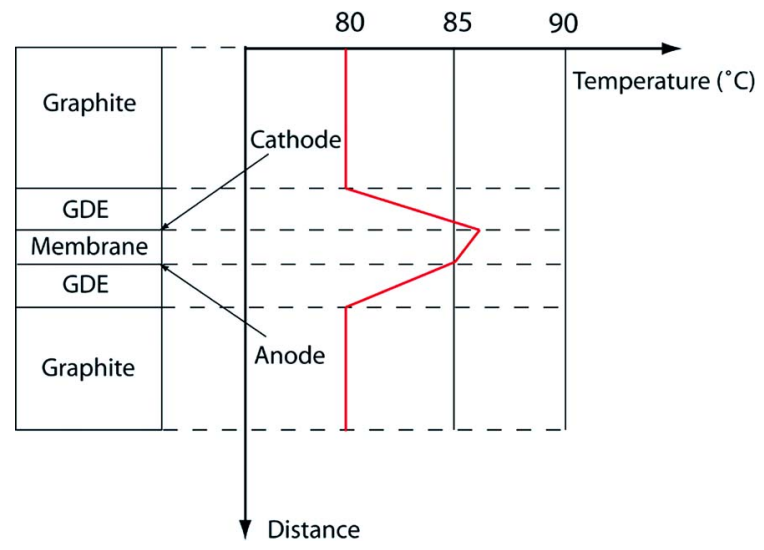

Fig. 1 The calculated temperature profile inside the unit fuel cell assuming a constant anode/GDE temperature of $85^{\circ} \mathrm{C}$ and cathode/GDE temperature of $86^{\circ} \mathrm{C}$ the membrane is taken as $35 \%$, and then increased to $100 \%$ to simulate operating conditions. Both temperature and relative humidity profiles are assumed to be constant in time and there are no internal heat-generation terms. Rather, stress generation arising from humidity and temperature changes have been modeled by applying step changes in temperature and relative humidity from the initial zero-stress state of room temperature, and 35\% relative humidity. Furthermore, this initial model assumes only linear elastic response of all components, and uses the further simplifying assumption that all the materials have isotropic thermal and humidity expansion behavior (except when noted) that are uncoupled. Also, the catalyst is assumed to be integrated into the GDE instead of considering this as a separate layer. Each of these simplifying assumptions will be relaxed in future work.

Using hygrothermoelasticity theory, we address the effects of temperature and moisture as well as the mechanical forces on the behavior of elastic bodies. In the present study, we consider only the uncoupled theory for which the additional temperature changes brought about by the strain are neglected. Also, within the context of linearity we assume that the total strain tensor, $\varepsilon_{i j}$, is the sum

$$
\varepsilon_{i j}=\varepsilon_{i j}^{M}+\varepsilon_{i j}^{T}+\varepsilon_{i j}^{S}
$$

where, $\varepsilon_{i j}^{M}$ is the contribution from the mechanical forces and $\varepsilon_{i j}^{T}$, $\varepsilon_{i j}^{S}$ are the temperature and swelling induced strains, respectively.

If $T_{0}$ is taken as a reference temperature and $T$ as the actual temperature, the thermal strains resulting from a change in temperature of a completely unconstrained isotropic volume are given by

$$
\varepsilon_{i j}^{T}=\alpha\left(T-T_{0}\right) \delta_{i j}
$$

$\alpha$ is the linear coefficient of thermal expansion, having units of $\mathrm{m} \mathrm{m}^{-1} \mathrm{~K}^{-1} . \delta_{i j}$ is the Kronecker symbol. Similarly, the swelling strains caused by moisture change are given by

$$
\varepsilon_{i j}^{S}=\beta_{i j}\left(C-C_{0}\right)
$$

where $\beta_{i j}$ is the swelling coefficient tensor due to moisture absorption; when the material is isotropic, $\beta_{i j}=\beta \delta_{i j}$. The swelling 

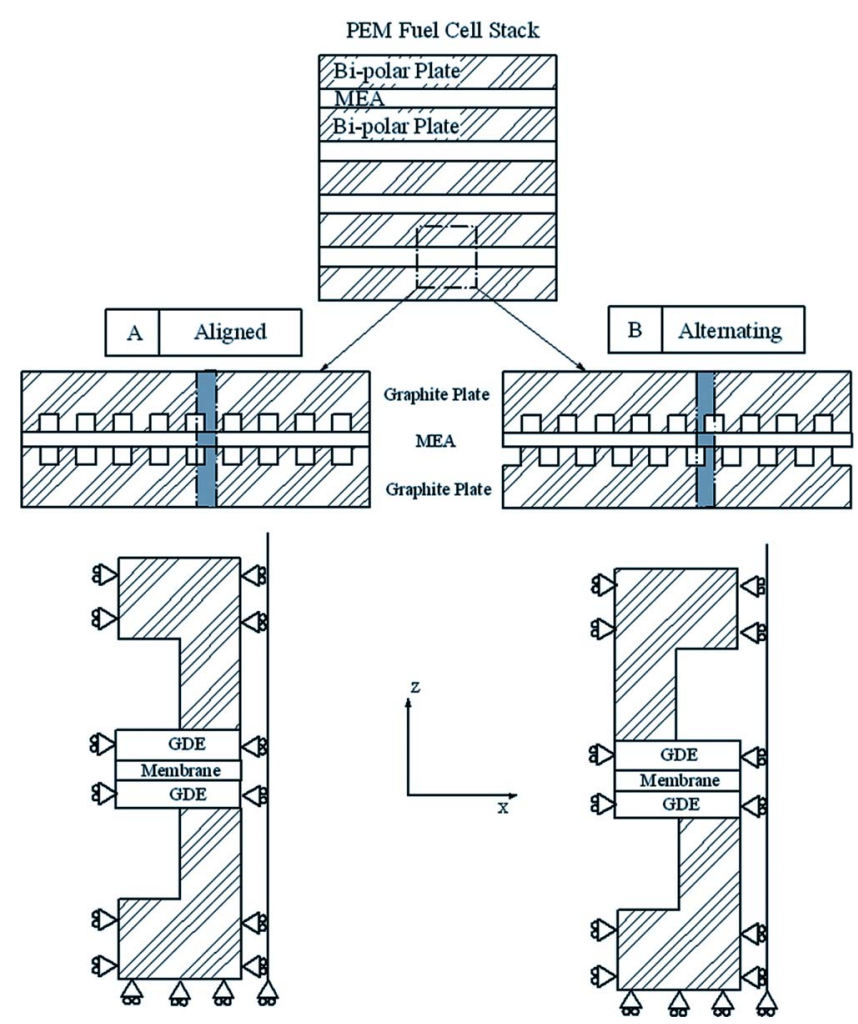

Fig. 2 Two different geometries have been modeled where the flow field has either (a) aligned or (b) alternating gas channels. The mechanical boundary conditions are noted in the figure. In addition, two additional boundary conditions (not shown) for case (a) and (b) were imposed by subjecting the stack to either constant displacement or constant load clamping at the top.

coefficient is usually defined as the relative change in length per $1 \%$ weight gain. Since, in the current application, relative humidity rather than water gain is assumed to be known as the swelling coefficient it is defined as the relative change in length per $1 \%$ relative humidity change. Then the units of $\beta$ are $\mathrm{m} / \mathrm{m} /(\%$ humidity change). $C$ is the relative humidity, and $C_{0}$ is the reference value for $C$.

From Hooke's Law and Eqs. (1)-(3), we have the hygrothermoelastic constitutive equation

$$
\varepsilon_{i j}=\frac{1+\nu}{E} \sigma_{i j}-\frac{\nu}{E} \delta_{i j} \sigma_{k k}+\alpha \Delta T \delta_{i j}+\beta_{i j} \Delta C
$$

where $\sigma_{k k}=\sigma_{11}+\sigma_{22}+\sigma_{33}$. Alternatively, expressing the stresses in terms of strain, we have,

$$
\begin{aligned}
\sigma_{i j}= & \frac{E}{(1+\nu)(1-2 \nu)}\left[\nu \delta_{i j} \varepsilon_{k k}+(1-2 \nu) \varepsilon_{i j}-(1+\nu) \alpha \Delta T \delta_{i j}-(1\right. \\
& \left.+\nu) \beta_{i j} \Delta C\right]
\end{aligned}
$$

where $\varepsilon_{k k}=\varepsilon_{11}+\varepsilon_{22}+\varepsilon_{33}$.

In our current study, the generalized plane strain condition is assumed. In this case, Eqs. (4) and (5) can be simplified by applying conditions

$$
\varepsilon_{13}=\varepsilon_{31}=\varepsilon_{23}=\varepsilon_{32}=0 \text { and } \varepsilon_{33}=\text { constant }
$$

A schematic drawing of a PEMFC unit cell is shown in Fig. 2. Two different graphite plate alignments are selected to study the effects of geometry of the flow field assembly. In both cases, the thickness of the plates is taken as $11 \mathrm{~mm}$. The depth and the width of grooves in the plate are $1 \mathrm{~mm}$. To investigate the effects of membrane thickness, three different membrane thicknesses are used: $25 \mu \mathrm{m}, 50 \mu \mathrm{m}$, and $100 \mu \mathrm{m}$. As mentioned previously, the
Table 2 Material properties used in finite element analysis

\begin{tabular}{cccccccc}
\hline \hline & & & & & & $\beta$ \\
& $k$ & $\rho$ & $E$ & & $\alpha$ & $10^{-6} / \%$ & $C_{p}$ \\
& $\mathrm{~W} / \mathrm{m} / \mathrm{K}$ & $\mathrm{kg} / \mathrm{m}^{3}$ & $\mathrm{MPa}$ & $\nu$ & $10^{-6} / \mathrm{K}$ & $\mathrm{RH}$ change & $\mathrm{J} / \mathrm{kg} / \mathrm{K}$ \\
\hline Graphite & 95 & 1800 & 10,000 & 0.25 & 5 & neglected & 750 \\
GDE & 0.3 & 400 & 10,000 & 0.25 & -0.8 & neglected & 500 \\
Membrane & 0.259 & 2000 & 249 & 0.25 & 123 & 2300 & 1050 \\
\hline \hline
\end{tabular}

catalyst layer is included in the gas diffusion layer, forming a gas diffusion electrode (GDE). In this model, the thickness of GDE is $100 \mu \mathrm{m}$.

The material properties used in this model are shown in Table 2 . The properties for the graphite plates are taken from commercial graphite, the carbon paper from TORAY® TGP-H-030 [19], and the membrane properties are from NAFION® [20]. From our ongoing research, the dimensional change of NAFION® from $35 \%$ to $100 \%$ relative humidity at $85^{\circ} \mathrm{C}$ is approximately $15 \%$. The units of $\beta$ we used in the model are $\mathrm{mm} / \mathrm{mm}$ per percent relative humidity change, giving the swelling coefficient for NAFION® as $2300\left(10^{-6} \mathrm{~mm} / \mathrm{mm}\right.$ per percent relative humidity change) [21].

Finite element models have been built for these different geometries, utilizing the commercial software, ABAQUS 6.4 [23]. A unit cell is selected from the assembly for analysis (as shown in Fig. 2). The boundary condition $u_{2}=0$ is applied on the bottom, and $u_{1}=0$ on the left-hand side, where $u_{i}$ is the deformation in the $i$ direction. A linear constraint $A_{1} u_{1}^{N_{1}}+A_{2} u_{1}^{N_{2}}=0$ is applied on the right side. For our problem, $A_{1}=1$ and $A_{2}=-1$ and $N_{1}$ and $N_{2}$ are node sets on the right-hand side. This condition constrains the right-hand side to displace uniformly. Four-node generalized plane strain temperature-displacement coupled elements CPEG4T are used in the FE analysis.

ABAQUS does not have a built-in module for moisture expansion. Instead, the subroutine UEXPAN [23] is used to define the strain from thermal expansion and swelling (both isotropic and anisotropic cases). UEXPAN outputs an eigenstrain based on the state of defined field variables. In the present case, humidity and temperature, along with their changes, are used as input to UEXPAN. The routine calculates the expansion caused by both the change in temperature and humidity.

The channels in the graphite plates are used for gas transport to and from the membrane. Typically, hydrogen is brought to the anode side of the MEA and air to the cathode, while water vapor is carried away. In some cases, the channels on either side of the MEA are aligned with each other, in other cases they are not. Thus, two plate alignments are investigated (see Fig. 2) to compare their effects on the stresses in the membranes. The cases where the grooves are aligned will be referred to as "aligned" and the nonaligned cases as "alternating." Our previous study [21] showed that the magnitudes of the stresses in the membrane are much higher than that in GDEs or the plates. Also, the mismatches in the thermal and swelling coefficients lead to compression in the membrane and bending in the GDE. This bending is especially pronounced in the alternating model.

Two different clamping methods are also investigated. The first method is fixed load, in which a constant pressure (1 MPa) is applied on the surface of the upper graphite plate; the second method is fixed displacement where the graphite plates are clamped, resulting in a net displacement in the thickness direction. In the fixed displacement models, the applied displacement is calculated by applying a $1 \mathrm{MPa}$ load to an otherwise unloaded model. The applied displacements for the various models are shown in Table 3. 
Table 3 Applied displacements used in the fixed displacement models

\begin{tabular}{ccc}
\hline \hline \multirow{2}{*}{ Model } & $\begin{array}{c}\text { Thickness of membrane } \\
(\mu \mathrm{m})\end{array}$ & $\begin{array}{c}\text { Displacement } \\
(\mu \mathrm{m})\end{array}$ \\
\hline \multirow{2}{*}{ Aligned } & 25 & -2.669 \\
& 50 & -2.813 \\
Alternating & 100 & -3.094 \\
& 25 & -3.310 \\
& 50 & -3.570 \\
& 100 & -3.982 \\
\hline
\end{tabular}

\section{Results and Discussions}

3.1 Effects of Plate Alignments and Clamping Methods. Figure 1 illustrates the temperature profile inside the fuel cell unit cell. Figures 3-5 show the distribution of the in-plane stress $\sigma_{x x}$, out-plane stress $\sigma_{z z}$, and shear stress $\sigma_{x z}$, respectively, for the case of membrane thickness $50 \mu \mathrm{m}$ and fixed loading. The directions $x, y$, and $z$ (Figs. 3-5) correspond to directions 1, 3, and 2 in Eqs. (1)-(6), respectively. In the finite element analysis, the initial relative humidity of the membrane is $35 \%$, and then increased to $100 \%$ to simulate operating condition. Both temperature and humidity profiles are assumed to be constant in time. These results show that the in-plane stress $\sigma_{x x}$ is the dominant stress in the membrane, and the shear stress is quite small compared to inplane and out-of-plane stresses. The different gas channel align-

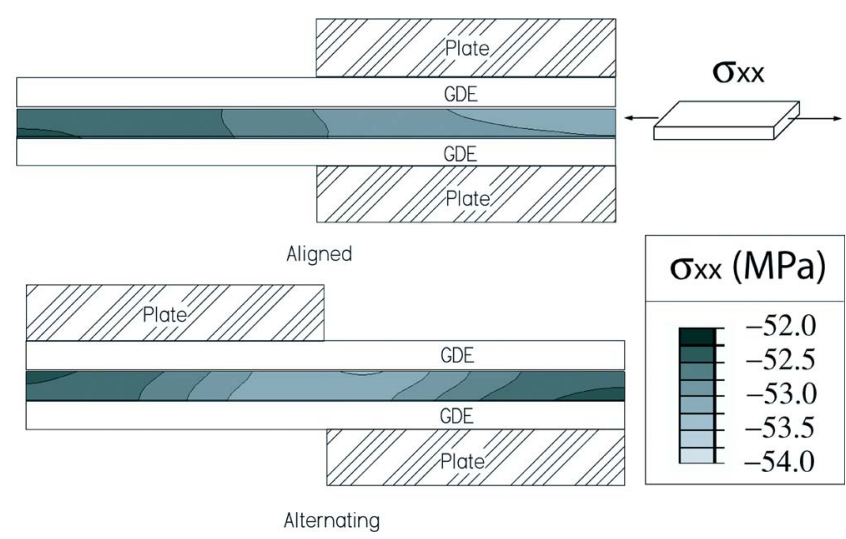

Fig. 3 In-plane stress $\left(\sigma_{x x}\right)$ distributions in the membrane for constant load of the stack for the aligned and alternating geometries

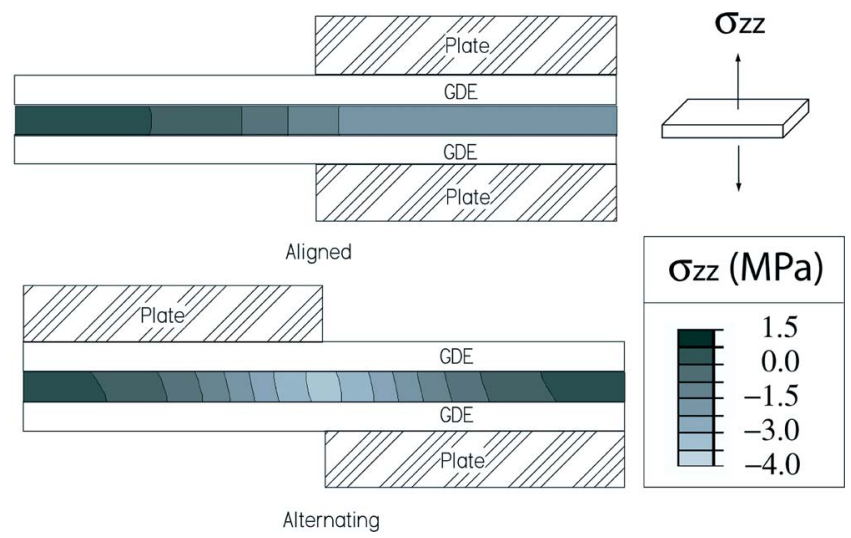

Fig. 4 Out-plane stress $\left(\sigma_{z z}\right)$ distributions in the membrane for constant load of the stack for the aligned and alternating geometries

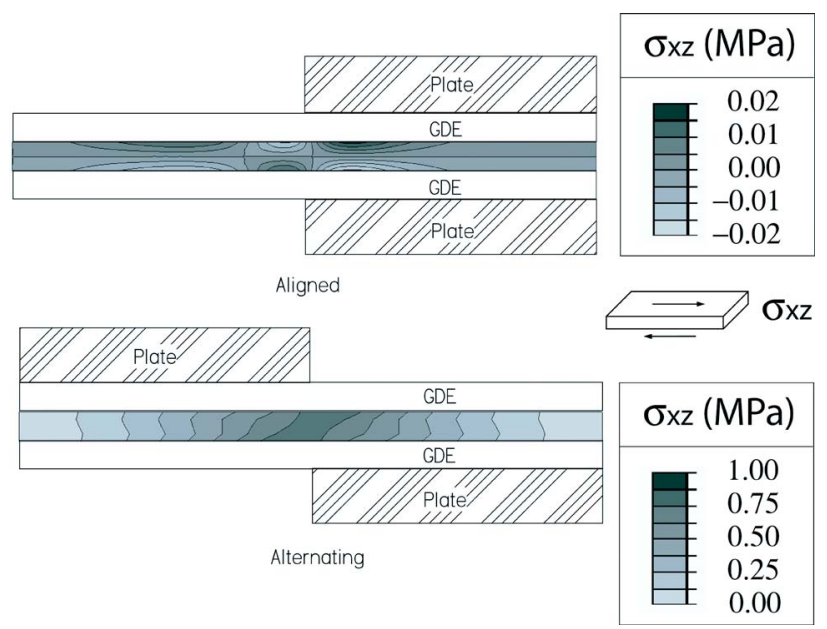

Fig. 5 Shear stress $\left(\sigma_{x z}\right)$ distributions in the membrane for constant load of the stack for the aligned and alternating geometries

ments also effect the stresses distributions. Figure 6 illustrates the stress distributions along the upper surface of the membrane as a function of the in-plane dimension " $x$." It is clear that the stresses (both $\sigma_{x x}$ and $\sigma_{z z}$ ) have the highest magnitudes in the middle of the unit cell in an alternating model, and along the edge in an aligned model. Fixed displacement clamping introduces much larger stresses in the membrane than fixed load clamping. Although the magnitudes of the differences in the stress distributions are not large, they can induce localized bending stresses, which can contribute to failure of the system.

3.2 Effect of Membrane Thickness. We also studied the influence of the membrane thickness on the stresses, assuming all other parameters remain unchanged. Figures 7-9 show that if the plates are subjected to a fixed load, changing the thickness of the

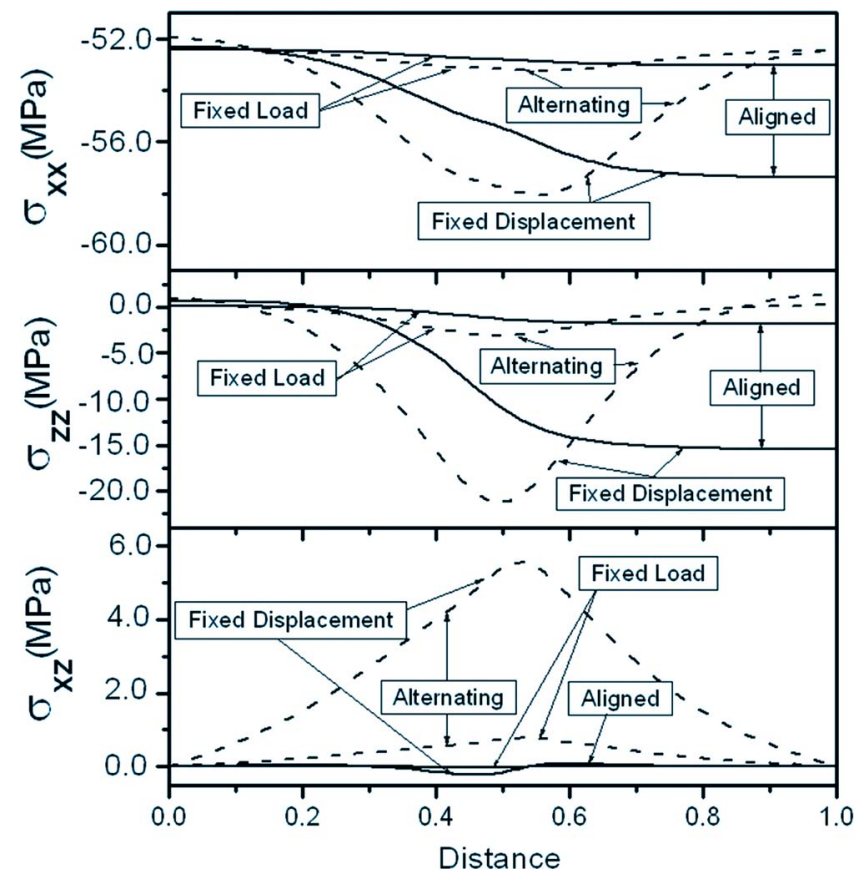

Fig. 6 A comparison of the stress distributions in the membrane along the upper surface of the membrane when using either constant load or constant displacement clamping methods for the two different gas channel alignments 


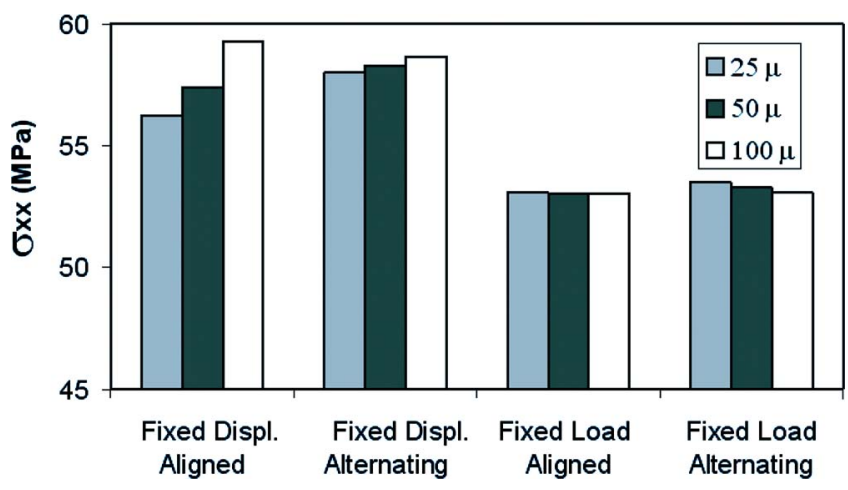

Fig. 7 The effect of thickness on the maximum in-plane stress $\left(\sigma_{x x}\right)$ in the membrane is greater in the case of aligned flow fields under fixed displacement clamping than in the other cases studied

membrane has a minor effect on $\sigma_{x x}$, but $\sigma_{x z}$ decreases as the thickness of the membrane increases in the alternating model. However, in the aligned model, $\sigma_{x z}$ increases as the membrane thickness increases. If the plates are subjected to fixed displacement, all stresses increase with the increase of the membrane thickness, no matter if the gas channel is aligned or alternating.

3.3 Investigation of Anisotropy of the Membrane. Five different anisotropic cases of the membrane are investigated (Table 4). Hygrothermal stresses in the membrane $(50 \mu \mathrm{m})$ under fixed

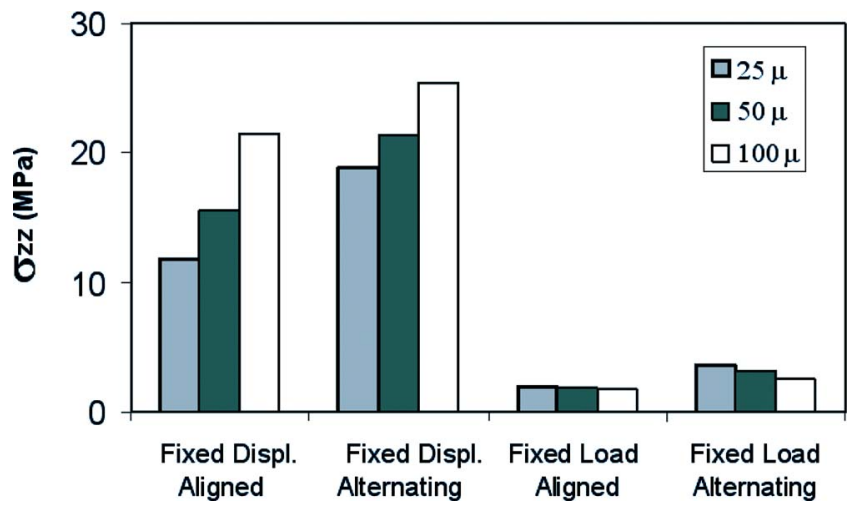

Fig. 8 The effect of thickness on the maximum out-plane stress $\left(\sigma_{z z}\right)$ in the membrane is greater when the under fixed displacement clamping than when under fixed load displacement

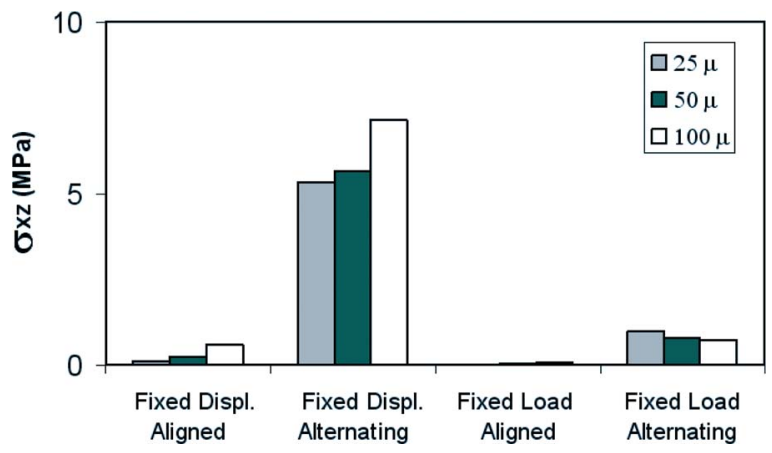

Fig. 9 The maximum shear stress $\left(\sigma_{x z}\right)$ in the membrane is relatively low in all cases, but highest when the flow fields are in the alternating geometry under fixed displacement clamping conditions
Table 4 Anisotropic swelling of the membrane

\begin{tabular}{lccccc}
\hline \hline & \multicolumn{5}{c}{ Swelling (\% length change from $35 \%$ to $100 \%$} \\
& relative humidity) \\
\cline { 2 - 6 } & $15-15-15$ & $5-5-15$ & $5-0-15$ & $0-5-15$ & $0-0-15$ \\
\hline$x$ direction & 15 & 5 & 5 & 0 & 0 \\
$y$ direction & 15 & 5 & 0 & 5 & 0 \\
$z$ direction & 15 & 15 & 15 & 15 & 15 \\
\hline \hline
\end{tabular}

displacement boundary condition are shown in Figures 10 and 11 . It is obvious that the highest stresses occur in isotropic membranes. Most significant anisotropy effects in the membrane are on in-plane stress $\sigma_{x x}$.

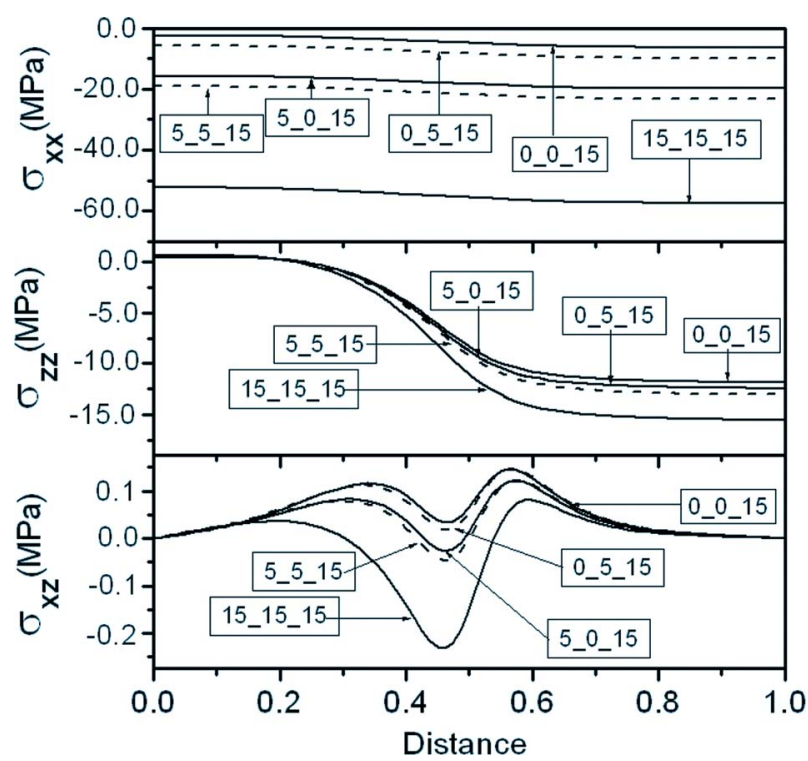

Fig. 10 The effects of anisotropy of the membrane swelling coefficient on the stress distributions in the membrane in aligned assembly

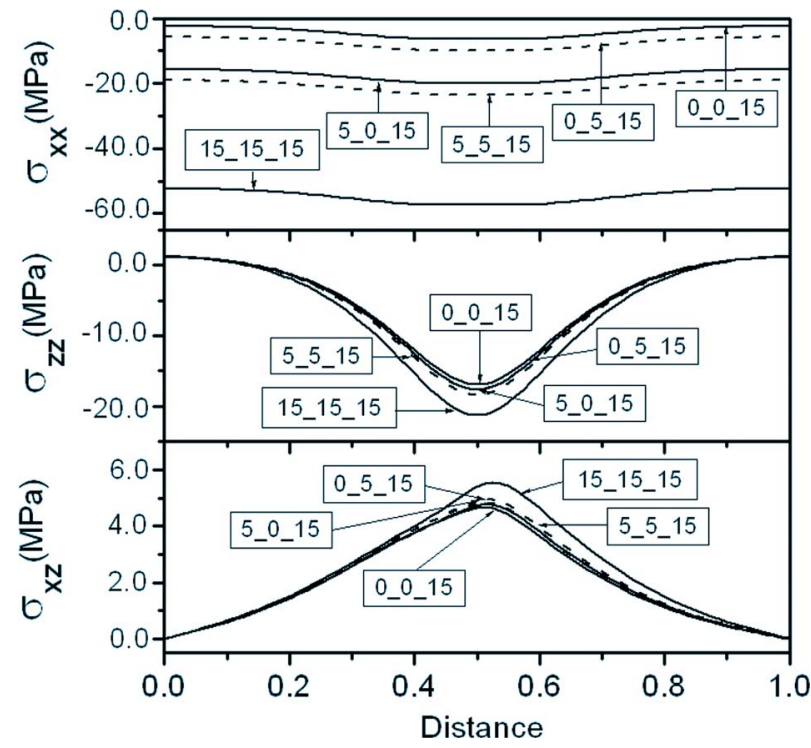

Fig. 11 The effects of anisotropy of the membrane swelling coefficient on the stress distributions in the membrane in alternating assembly 


\section{Conclusions}

The finite element method is used to investigate the hygrothermal stresses in fuel cell unit cell assemblies caused by temperature and relative humidity changes. The analysis shows that the inplane stress is the dominant stress in the membrane. Nonuniform distribution of stresses, caused by the temperature gradient in the MEA, induces localized bending stresses, which can contribute to delamination between the membrane and the GDE. Comparison of the results for aligned and alternating alignment of the bipolar plates shows that the alignment of the gas channels affects the stresses distributions. In general, aligned gas channels produce smaller hygrothermal stresses than alternating channels. This analysis shows that fixed displacement fuel cell assemblies introduce larger stresses in the membrane than fixed load assemblies. Influence of membrane thickness is also studied, which shows a less significant effect. Isotropic membranes introduce the highest stresses in the membrane, and the most significant anisotrophy effects in the membrane are on in-plane stress.

\section{Acknowledgment}

This research has been supported by grants from the U.S. Department of Energy, and W.L. Gore and Associates, Inc.

\section{References}

[1] Benziger, J. B., and Kevrekidis, I. G., 2003, "Polymer Electrolyte Membrane Fuel Cell Reactors," AIChE Annual Meeting, San Francisco, CA

[2] Bossel U. G., 1999, "Portable Fuel Cell Charger with Integrated Hydrogen Generator," in Proceedings of the European Fuel Cell Forum Portable Fuel Cells Conference, Lucerne, pp. 79-84.

[3] DOE Multi-Year Research, "Development and Demonstration Plan Planned Activities for 2003-2010 (Draft 6/3/03)," p. 7, Section 3.4.4, available at 〈http://www.eere.energy.gov/hydrogenandfuelcells/mypp/〉.

[4] Fuller, T. F., and Newman, J., 1993, "Water and Thermal Management in Solid-Polymer-Electrolyte Fuel Cells," J. Electrochem. Soc., 140, pp. 1218 1225 .

[5] Stanic, V., 2004, "Mechanism of Pin-hole Formation in Membrane Electrode Assemblies for PEM Fuel Cells," 4th International Symposium on Proton Conducting Membrane Fuel Cells, October.

[6] Liu, W., Ruth, K., and Rusch, G., 2001, "Membrane Durability in PEM Fuel Cells," J. New Mater. Electrochem. Syst., 4, pp. 227-231.

[7] Webber, A., and Newman, J., 2004, "A Theoretical Study of Membrane Con- straint in Polymer-Electrolyte Fuel Cell," AIChE J., 50(12), pp. 3215-3226.

[8] Beuscher, U., Rusch, G., Shimpalee, S., and Van Zee, J. W., 2002, "Investigation of Gas Diffusion Media using CFD Modeling," 202nd Meeting of the Electrochemical Society, Salt Lake City, UT, paper No. 861.

[9] Shimpalee, S., Van Zee, J. W., and Beuscher, U., 2004, "Investigation of GDM Flooding Effects on PEMFC Performance," 206th Meeting of the Electrochemical Society, Honolulu, HI, paper No. 1931.

[10] Shimpalee, S., Beuscher, U., and Van Zee, J. W., 2005, "Investigation of Gas Diffusion Media inside PEMFC using CFD Modeling," AIChE J. (accepted).

[11] Dong, Q., Shields, D., Mench, M. M., Cleghorn, S., and Beuscher, U., 2004, "Distributed Performance of Polymer Electrolyte Fuel Cells under Low Humidity Conditions," 206th Meeting of the Electrochemical Society, Honolulu, HI, paper No. 1978.

[12] Dong, Q., Shields, D., Mench, M. M., Cleghorn, S., and Beuscher, U., 2005, "Distributed Performance of Polymer Electrolyte Fuel Cells under Low Humidity Conditions," J. Electrochem. Soc. 152, pp. A2114-A2122.

[13] Ju, H., Wang, C.-Y., Cleghorn, S., and Beuscher, U., 2005, "Non-Isothermal Modeling of Polymer Electrolyte Fuel Cells-Part I: Experimental Validation," J. Electrochem. Soc. 153, pp. A248-A254.

[14] Lee, W.-K., Shimpalee, S., and Van Zee, J. W., 2003, "Verifying Predictions of Water and Current Distributions in a Serpentine Flow Flow Field Polymer Electrolyte Membrane Fuel Cell," J. Electrochem. Soc., 150, pp. A341-A348.

[15] Berning, T., and Diilali, N., 2003, "A 3D, Multiphase, Multicomponent Model of the Cathode and Anode of a PEM Fuel Cell," J. Electrochem. Soc., 150, pp. A1596-A1607.

[16] Um, S., and Wang, C. Y., 2004, "Three-Dimensional Analysis of Transport and Electrochemical Reactions in Polymer Electrolyte Fuel Cells," J. Power Sources, 125, pp. 40-51.

[17] Hwang, J. J., Chen, C. K., Savinell, R. F., Liu, C. C., and Wainright, J., 2004, "A Three-Dimensional Numerical Simulation of the Transport Phenomena in the Cathodic Side of a PEMFC," J. Appl. Electrochem., 34, pp. 217-224.

[18] Shimpalee, S., and Dutta, S., 2000, "Numerical Prediction of Temperature Distribution in PEM Fuel Cells," Numer. Heat Transfer, Part A, 38, pp. 111128.

[19] Product Information, Toray Industries, Inc.

[20] Product Information, 2004, DuPont Nafion PFSA Membranes N-112, NE1135, N-115, N-117, NE-1110 Perfluorosulfonic Acid Polymer. NAE101.

[21] Tang, Y., Santare, M. H., Karlsson, A. M., Cleghorn, S., Johnson, W. B., "Stresses in Proton Exchange Membranes Due to Hydration and Dehydration Cycles," Proceedings of the 3rd International Conference on Fuel Cell Science, Engineering and Technology, May 23-25, Ypsilanti, Michigan.

[22] Lai, Y., Mittelsteadt, C. K., Gittleman, C. S., and Dillard, D. A., 2005, "Viscoelastic Stress Model and Mechanical Characterization of Perfluorosulfonic Acid (PFSA) Polymer Electrolyte Membranes," Proceedings of the Third International Conference on Fuel Cell Science, Engineering and Technology, May 23-25, Ypsilanti, Michigan.

[23] ABAQUS Analysis User's Manual, 2003, Hibbitt, Karlsson, and Sorensen. 